\title{
On-Pump Cardiopulmonary Bypass Versus Off-Pump Coronary Artery Bypass Grafting Surgery: Renal And Liver Function Tests
}

\author{
Pompada Kardiyopulmoner Bypass ve Pompasız Koroner Arter Bypass Greftleme Cerrahi Tekniklerinin \\ Karşılaştırılması: Böbrek ve Karaciğer Fonksiyon Testleri
}

Huseyin Bayram, Mustafa Hakan Zor, Dilek Erer, Erkan Iriz, Mehmet Emin Ozdogan, Levent Oktar

Department of Cardiovascular Surgery, Gazi University Faculty of Medicine, Ankara, Turkey

\begin{abstract}
Objective: Cardiopulmonary bypass (CPB) triggers systemic inflammation. Inflammatory system activation may cause deteoriation in liver and renal functions. In our study we aimed to search the effect of on-pump CPB and beating heart off-pump coronary artery bypass grafting (CABG) surgery techniques on renal and liver functions.

Methods: Sixty four patients who underwent coronary artery surgery were included in the study and were divided into two groups: on-pump CPB group (40) and beating heart off-pump CABG group (24), prospectively. The blood samples were collected for preoperative and postoperative levels of blood urea nitrogen (BUN), creatinine, aspartate aminotransferase (AST), alanine aminotransferase (ALT), and AST to ALT ratio at $24^{\text {th }}$ and $48^{\text {th }}$ hours.

Results: Clinical and demographic features were similar in both groups. There were no statistically significant difference in levels of preoperative BUN, creatinine, AST, ALT, AST to ALT ratio. The postoperative $24^{\text {th }}$ hour plasma levels of creatinine, AST and AST/ALT were lower in beating heart off-pump CABG group but BUN and ALT levels were similar among the two groups. The postoperative $48^{\text {th }}$ hour plasma levels of BUN, creatinine, AST and AST/ALT were lower in beating heart off-pump CABG group but levels of ALT were similar in both groups.

Conclusion: Based on our findings we conclude that beating heart off-pump CABG has lower negative effect on liver and renal function than on-pump CPB. Abstract of this manuscript was presented in 7th Congress of Update in Cardiology and Cardiovascular Surgery in association with TCT Mediterranean as a poster.
\end{abstract}

Key Words: Acute kidney injury, cardiopulmonary bypass, coronary artery bypass, coronary artery bypass, off-pump, liver.

Received: 07.29.2013

Accepted: 07.10.2015
ÖZET

Amaç: Kardiyopulmoner bypass sistemik inflamasyonu tetikler. Inflamatuar sistem aktivasyonu ise karaciğer ve böbrek fonksiyonlarında tahribat yapabilir. Biz bu çalışmamızda çalışan kalpte pompasız koroner arter bypass greftleme (KABG) ile pompalı kardiopulmoner bypass (KPB) cerrahi tekniklerinin böbrek ve karaciğer fonksiyonları üzerine olan etkilerini araştırmayı amaçladık.

Gereç ve Yöntemler: Koroner arter bypass cerrahisine giden 64 hasta çalışmaya alındı. Hastalar prospektif olarak pompada KPB $(n=40)$ ve çalışan kalpte pompasız KABG $(n=24)$ olmak üzere 2 gruba ayrıldı. Hastaların kan örnekleri preoperatif, postoperatif 24 . ve 48. saatlerde kan üre azotu (BUN), kreatinin, aspartate aminotransferase (AST), alanine aminotranferease (ALT) ve AST / ALT oranına bakılması için toplandı.

Bulgular: Her 2 grupta preoperatif klinik ve demografik özellikler benzerdi (Tablo 1). Her iki grubun operasyon öncesi BUN, kreatinin, AST, ALT ve AST /ALT oranları arasında istatistiksel olarak anlamlı fark yoktu. Operasyon sonrası 24. saat kreatinin, AST ve AST/ALT oranları, çalışan kalpte pompası KABG grubunda düşük olup, BUN ve ALT oranları her iki grupta benzer bulundu. Operasyon sonrası 48. saat BUN, kreatinin, AST ve AST/ALT oranları, çaılşan kalpte pompası KABG grubunda düşük olup ALT düzeyleri her iki grupta benzer bulundu.

Sonuç: Çalışmamızda çalışan kalpte pompasız KABG'nin, pompalı KPB'a göre böbrek ve karaciğer fonksiyonu üzerine olan olumsuz etkilerinin daha az olduğunu saptadık.

Anahtar Sözcükler: Akut böbrek hasarı, kardiyopulmoner bypass, koroner arter bypass, off-pump koroner arter bypass graftleme, karaciğer.

Geliş Tarihi: 29.07.2013

Kabul Tarihi: 10.07.2015

Bu yazının özeti 7. Kardiyoloji ve Kardiyovasküler Cerrahide Yenilikler kongresinde poster olarak sunulmuştur. 


\section{INTRODUCTION}

Cardiac surgery has progressed much in the last forty years. Inflammatory system activation triggered by cardiopulmonary bypass (CPB) may lead to a variety of complications including respiratory insufficiency, lung damage, cognitive dysfunction and brain damage (1-3). In the recent years, off-pump CABG procedure has been being performed more frequently without the need of $\mathrm{CPB}$. The principal goal is to avoid the negative effects of cardiopulmonary bypass on physiological systems (4-6). CPB induced systemic inflammation activation may cause deteoriation in liver and renal functions contrubuting to increased morbidity and mortality (3-5). In the present study, we aim to investigate the effects of off-pump and on-pump CABG procedures on renal and liver functions.

\section{METHODS}

The study was approved by local ethical commitee, and informed consent forms were signed by all patients. All reported research involving "Human beings" conducted in accordance with the principles set forth in the Helsinki Declaration 2008. The patients were prospectively divided into two groups according to the use of extracorporeal circulation or not as follows: off-pump CABG group $(n=24)$ and on-pump CPB group $(n=40)$. Patients were assigned to an off-pump or on-pump strategy based upon surgeons' preference.

Exclusion criteria were as follows: occurrence of an acute myocardial infarction within one month, need for emergency coronary revascularization, creatinine level $>2 \mathrm{mg} / \mathrm{dL}$ and/or the presence of acute renal failure, presence of an active infectious disease, presence of a systemic inflammatory disease, presence of a collagen tissue disorder, presence of a metastatic disease, being a patient receiving immunosuppressive medication and reoperation for bleeding. Premedication and Anesthesia

All patients were premedicated by $10 \mathrm{mg}$ oral diazepam 12 hours before the operation, $0.1 \mathrm{mg} / \mathrm{kg}$ subcutaneous morphine sulfate and $20-50 \mathrm{mg} / \mathrm{kg}$ intravenous cefazoline sodium 30 minutes before the operation. Patients were monitorized for DII standard derivation in the operative room. Anesthesia was induced by $5-7 \mathrm{mg} / \mathrm{kg}$ sodium thiopental. For the maintenance of anesthesia, $0.1 \mathrm{mg} / \mathrm{kg}$ pancuronium was administered as a muscle relaxant, $0.1-0.5 \mathrm{mcg} / \mathrm{kg}$ remifentanyl continuous infusion was administered as an analgesic. Isofloran was used as inhaled anesthetic as necessary.

Off-pump CABG technique

After median sternotomy, all patients were anticoagulated with 100-200 $\mathrm{U} / \mathrm{kg}$ of heparin. An Octopus IV tissue stabilizer (Medtronic, Minneapolis, USA) was used for partial immobilization of the myocardial surface during the construction of distal anastomoses. An intracoronary shunt was placed for the vessel to be anastomosed. The heart was positioned using deep pericardial traction, Starfish heart positioner (Medtronic, Minneapolis, USA) and an apical suction device. Heart rate control was achieved preferably by esmolol infusion. Revascularization of the right coronary artery (RCA) was performed first, followed by the construction of distal anastomoses of the circumflex (Cx) artery territory, and the left anterior descending artery (LAD) territory. The left internal mammary artery (LIMA) was anastomosed to the LAD in all patients. Following the construction of distal anastomoses, the saphenous vein grafts were anastomosed to the aorta.

CPB technique

The patients were anticoagulated with $300-400 \mathrm{U} / \mathrm{kg}$ of heparin. CPB was initiated following cannulation of the aorta and the right atrium in a standart fashion. A Stockert SIII roller pump (Stockert Instrumente $\mathrm{GmbH}$, Munich, Germany), a membrane type oxygenator and an uncoated CPB circuit (Dideco Compact Flo Evo, Sorin Group, Italy) were used. The pump prime solution contained $1000-1500 \mathrm{~mL}$ of lactated Ringer's solution to maintain a hematocrit level of $\% 26 \pm 2$. Pump flow was set at $2.2-2.4 \mathrm{~L} / \mathrm{m}^{2} /$ minutes to maintain mean arterial pressure between $50-70 \mathrm{mmHg}$. Moderate hypotermia and cold blood cardioplegia administered in every 20 minutes in antegrade and retrograde fashion was used. Additional cold $\left(4{ }^{\circ} \mathrm{C}\right)$ Isolyte $\mathrm{S}$ solution was topically applied onto the surface of the heart at the same intervals.

Sample collection

The blood samples were collected at preoperative and postoperative $24^{\text {th }}$ and $48^{\text {th }}$ hour. Blood samples were analyzed for BUN, AST, ALT and AST to ALT ratio.

Statistical Analysis

SPSS 13.0 packet program (SPSS Inc., Chicago, IL) was used for the statistical analysis of the parameters obtained from the blood analysis results..
Descriptive statistics were shown as mean \pm standard deviation. The statistical significances between two groups were assessed by Mann-Whitney $U$ test. Chisquare test was used to assess differences of categorical variables between groups. Pearson's analysis was used to calculate the correlation coefficients. Values of $\mathrm{P}<0.05$ were accepted as statistically significant.

\section{RESULTS}

Demographic and laboratory data with comparative results are listed in Table 1. No statistically significant difference was detected between the groups for age, body mass index, hypertension, diabetes mellitus, hyperlipidemia, smoking, myocardial infarction, ejection fraction or the number of grafts $(P>0.05)$. There were no statistically significant difference in preoperative BUN, creatinine, AST, ALT, AST/ALT ratio measurements (Table 2). The postoperative $24{ }^{\text {th }}$ hour plasma levels of creatinine, AST and AST/ALT ratio were lower in offpump group but BUN and ALT levels were similar between the two groups. The postoperative $48^{\text {th }}$ hour plasma levels of BUN, creatinine, AST and AST/ALT ratio were lower in off-pump group, but levels of ALT were similar between the two groups (Table 2).

Table 1. Baseline characteristics of the patient groups

\begin{tabular}{|c|c|c|c|c|}
\hline & & $\begin{array}{l}\text { Off-pump } \\
\text { CABG }(n=24)\end{array}$ & $\begin{array}{l}\text { on-pump } \\
\text { CPB }(n=40)\end{array}$ & $\begin{array}{l}p \\
\text { value }\end{array}$ \\
\hline Age (year) & mean $\pm S D$ & $60.4 \pm 11.3$ & $61.9 \pm 9.4$ & 0.40 \\
\hline Sex (male) & n (\%) & $18(\% 75)$ & 31 (\%77.5) & 0.16 \\
\hline BMI $\left(\mathrm{kg} / \mathrm{m}^{2}\right)$ & mean $\pm S D$ & $26.5 \pm 4.5$ & $28.5 \pm 3.2$ & 0.50 \\
\hline DM & $\mathrm{n}(\%)$ & $11(\% 46)$ & $20(\% 50)$ & 0.26 \\
\hline HT & n (\%) & $13(\% 54.2)$ & $23(\% 57.5)$ & 0.72 \\
\hline Hyperlipidemia & n (\%) & 9 (\%37.5) & $12(\% 30)$ & 0.74 \\
\hline Smoking & $\mathrm{n}(\%)$ & $13(\% 54.2)$ & $20(\% 50)$ & 0.23 \\
\hline $\begin{array}{l}\text { History of } \mathrm{MI} \text { (before } \\
\text { the last month) }\end{array}$ & $\mathrm{n}(\%)$ & $6(\% 54.5)$ & $5(\% 45.5)$ & 0.18 \\
\hline$E F(\%)$ & mean $\pm S D$ & $47.5 \pm 11.2$ & $48.3 \pm 12.6$ & 0.37 \\
\hline $\begin{array}{l}\text { Mean number of } \\
\text { bypass grafts }\end{array}$ & mean $\pm S D$ & $3.1 \pm 0.5$ & $3.3 \pm 0.4$ & 0.41 \\
\hline
\end{tabular}

BMI: body mass index; CABG: coronary artery bypass grafting; CPB: cardiopulmonary bypass; DM: diabetes mellitus; EF: ejection fraction; HT: hypertension; MI: myocardial infarction; SD: standard deviation.

Table 2. Renal and liver function test results in study groups

\begin{tabular}{llll}
\hline & $\begin{array}{l}\text { Off-pump } \\
\text { CABG }\end{array}$ & $\begin{array}{l}\text { on-pump } \\
\text { CPB }\end{array}$ & p value \\
\hline PrO BUN (mmol/L) & $19.7 \pm 9.3$ & $19.4 \pm 6.5$ & 0.93 \\
PrO creatinine(mg/dl) & $1.15 \pm 0.26$ & $1,15 \pm 0.36$ & 0.96 \\
PrO AST (U/L) & $23.3 \pm 9.8$ & $21.4 \pm 8.7$ & 0.60 \\
PrO ALT (U/ml) & $25.8 \pm 11.5$ & $23.8 \pm 12.7$ & 0.67 \\
PrO AST to ALT ratio & $0.96 \pm 0.37$ & $1.03 \pm 0.60$ & 0.68 \\
24hrs PO BUN (mmol/L) & $17.3 \pm 5.3$ & $21.3 \pm 8.3$ & 0.11 \\
24hrs PO creatinine(mg/dl) & $1.03 \pm 0.20$ & $1.23 \pm 0.28$ & 0.03 \\
24hrs PO AST (U/L) & $24.9 \pm 11.7$ & $58.2 \pm 44.1$ & 0.004 \\
24hrs PO ALT (U/ml) & $23.7 \pm 13.8$ & $31.7 \pm 27.9$ & 0.29 \\
24hrs PO AST to ALT ratio & $1.21 \pm 0.71$ & $2.12 \pm 0.92$ & 0.004 \\
48hrs PO BUN (mmol/L) & $19.2 \pm 6.0$ & $25.8 \pm 8.0$ & 0.01 \\
48hrs PO creatinine (mg/dl) & $1.13 \pm 0.15$ & $1.32 \pm 0.29$ & 0.02 \\
48hrs PO AST (U/L) & $38.6 \pm 18.2$ & $94.4 \pm 82.5$ & 0.008 \\
48hrs PO ALT (U/ml) & $25.4 \pm 13.5$ & $36.7 \pm 22.1$ & 0.12 \\
48hrs PO AST to ALT ratio & $1.63 \pm 0.62$ & $2.69 \pm 1.07$ & 0.001 \\
\hline
\end{tabular}

ALT: alanine aminotranferease, AST: aspartate aminotransferase, BUN: blood urea nitrogen, CABG: coronary artery bypass grafting, CPB: cardiopulmonary bypass, PrO: preoperative, PO:postoperative. 


\section{DISCUSSION}

Cardiac operations using cardiopulmonary bypass lead to activation of systemic inflammation. During CPB, inflammatory response initiates with contact of heparinized blood to nonendothalial surfaces. Leukocyte levels decrease as a response to hemodilution initially, but after terminating CPB, it increases moderately. Neutrophils attach to synthetic surfaces, to each other or to platelets and monocytes leading to cell activation. Interleukin-1 (IL-1), TNF- $\alpha$, IL-6, IL-8, Interleukin-10 (IL-10), complement5b-9 (C5b-9), factor XIla, heparin, histamine, hypochlorous acid and arachidonic acid metabolites including leukotriene B4 (LTB4), platelet activating factor (PAF) and thromboxane $A 2$, prostaglandins and vasoactive cytotoxic substances are released by these activated cells and mediate most of the findings of "systemic inflammatory response syndrome" (SIRS) associate with CPB and cardiac surgery (7-9).

Cardiopulmonary bypass and systemic inflammation cause important morbidity and mortality following open heart surgery. Combination treatment of steroids and antioxidants in order to prevent and treat these conditions may decrease postoperative morbidity. Off-pump CABG procedure has the advantage to exclude the negative effects of CPB. Performing coronary artery bypass graft ( $C A B G$ ) operation without $C P B$ seems to be superior for decreasing inflammatory response. Off-pump surgery procedure has dramatically expanded coronary surgery indications in the recent years. Various studies have reported the relative advantages of this procedure compared to conventional CPB particularly for elder patients, cases with low ejection fraction, cerebrovascular diseases, liver disease, malign diseases, patient groups with bleeding anomalies or when utilization of blood and blood products is not allowed (4-6).

Many studies investigated the effects of off- pump and on- pump techniques on inflammation. Okubo et.al. analyzed the effects of off-pump/on-pump coronary surgery on IL-1, IL-8, IL-10 and TNF- $\alpha$ levels, and showed a significant increase in inflammatory markers in on-pump group while no difference in offpump CABG group was detected (10). Another study evaluating the effects of off- pump / on-pump surgery on endothelial activation and inflammatory response, concluded that off-pump CABG group has lower increase in vascular endothelial growth factor (VGEF) and monocyte chemo-attractant protein (MCP)-1), inflammatory markers and cytokine response (11).

Ascione et. al. (12) evaluated the effects of off- pump and on- pump CABG on the liver functions, and showed higher AST - ALT levels in the first postoperative day for on-pump group, but no difference in the monoethylglycinexylidide/ lidocaine ratio was seen. Yamada et. al. (13) analyzed the effects of off- pump/on- pump surgery on liver function analyzing alcohol dehydrogenase and alpha-glutathione S- transferase,. They showed an increase in serum alcohol dehydrogenase and alpha- glutathione S- transferase levels for off-pump group compared with on-pump CPB group. Both groups showed no clinical liver dysfunction. In the present study, $24^{\text {th }}$ hour postoperative AST and AST/ALT ratio were lower in off-pump group and ALT levels were found to be similar in both groups. The Forty-eight hour postoperative AST and AST/ALT ratio were lower in off-pump group, and ALT levels were similar in both groups. In patients undergoing on-pump coronary surgery, possible factors causing liver dysfunction may be the decrease in systemic vascular resistance, low CPB pressure, inflammatory activation and microemboluses $(14,15)$. Fifty percent of patients undergoing CABG was shown to have temporary intestinal mucosal ischemia indicated by intramucosal acidosis. Temporary intestinal mucosal ischemia increases the permeability of intestinal mucosa to bacteria and endotoxins. Liver helps cleaning cytokines and bacteria originating from intestines (16). This mechanism is disturbed in patients with liver dysfunction. Expansion of endotoxins and bacteria is an important factor contributing to systemic inflammatory response and to multiple organ failure (17).

Renal dysfunction is an important complication of CPB and is associated with increased mortality, morbidity and hospital stay $(18,19)$. It's pathogenesis is multifactorial and preexisting renal disease, elderly age and postoperative low cardiac output are general risk factors. Pump duration in CPB, low CPB pressure, systemic inflammatory response, and postoperative hypoperfusion are presumed mechanisms causing renal dysfunction $(20,21)$.
Renal dysfunction due to CPB can be prevented with off-pump CABG. Loef BG et. al. (18) investigated the effects of off-pump /on-pump surgery on renal functions concluding that lower microalbuminuria and higher creatinine clearance was associated with off-pump CABG. Another study by Pramodh $\mathrm{K}$ et. al. (19) showed that postoperative $24^{\text {th }}$ and $48^{\text {th }}$ hour creatinine clearance was significantly lower in on-pump group compared with off-pump group. In our study, postoperative $24^{\text {th }}$ hour creatinine value was lower in off-pump CABG group and BUN was similar in both groups. Postoperative $48^{\text {th }}$ hour BUN and creatinine values were found to be lower in off-pump patients compared with on-pump group.

Hypothermia is a beneficial strategy for visceral organ protection during CPB. The protective effects of hypothermia on organ function in the setting of ischemic injury have been previously demonstrated in animal models. It is also found to have attenuating effects in acute renal failure and liver dysfunctions. However, Boodhwani et al reported that, re-warming while on CPB has been associated with increased renal injury and should be avoided (22). Hypothermia has little effect on hepatic arterial blood flow and may actually increase portal flow. There is no significant difference in hepatic blood flow between pulsatile and non- pulsatile perfusion at high flow rates $\left(2.4 \mathrm{~L} / \mathrm{min} / \mathrm{m}^{2}\right)$ during hypothermia. The increase in total body oxygen consumption in the immediate hours after CPB may have an important role for development of inadequate gastrointestinal perfusion (23.24).

\section{CONCLUSION}

Our study has some limitations. The small number of patients enrolled in this study may have effected the precision of the outcomes. As moderate hypothermia was used for on-pump CABG and normotermia is naturally a part of off-pump surgery, temperature differences between two procedures may have altered the results of the laboratory findings as well. In conclusion, the results of this study suggest that off-pump CABG offers better than on-pump procedure in terms of negative consequences on renal and liver functions.

Conflict of Interest

No conflict of interest was declared by the authors.

\section{REFERENCES}

1. Chello M, Mastroroberto P, Quirino A, Cuda G, Perticone F, Cirillo F, et al. Inhibition of neutrophil apoptozis after coronary bypass operation with cardiopulmonary bypass. Ann Thorac Surg 2002;73:123-9.

2. Hazama S, Eishi K, Yamachika S, Noquchi M, Ariyoshi T, Takai H, et al. Inflammatory response after coronary revascularization: off-pump versus onpump (heparin coated circuits and poly2 methoxyethylacilate coated circuits) Ann Thorac Surg 2004;10:90-6.

3. Stamou SC, Corso PJ. Coronary revascularization without cardiopulmonary bypass in high-risk patients: A route to the future. Ann Thorac Surg 2001;71:1056-61.

4. Kiziltepe U, Tasoz R, Aral A, Elalmis AO, Eyileten ZB, Sirlak M et al. Clinical effects of combination of steroids and antioxidants following coronary artery bypass surgery. Turkiye Klinikleri J Cardiovascular Surgery 2003;4:33-9.

5. Ricci M, Karamanukian HL, Abraham R, Von Fricken K, D'Ancona G, Choi S, et al. Stroke in octogenarians undergoing coronary artery surgery with and without cardiopulmonary bypass. Ann Thorac Surg 2000;69:1471-5.

6. Koutlas TC, Elbeery JR, Williams JM, Moran JF, Francalancia NA, Chitwood WR Jr. Myocardial revascularization in the elderly using beating heart coronary artery bypass surgery. Ann Thorac Surg 2000;69(4):1042-7.

7. Butler J, Rocker GM, Westaby S. Inflammatory response to cardiopulmonary bypass. Ann Thorac Surg 1993;55:552-9.

8. Khabar KS, elBarbary MA, Khouqeer $F$, Devol E, al-Gain $S$, al-Halees $Z$. Circulating endotoxin and cytokines after cardiopulmonary bypass: differential correlation with duration of bypass and systemic inflammatory response/ multiple organ dysfunction syndromes. Clin Immunol Immunopathol 1997;85:97-103.

9. Yucel SM, Keceligil HT. Cardiopulmonary bypass. Turkiye Klinikleri J Cardiovasc Surg-Special Topics 2013;5:5-8. 
10. Okubo N, Hatori N, Ochi M, Tanaka S. Comparison of m-RNA expression for inflammatory mediators in leukocytes between on-pump and off-pump coronary artery bypass grafting. Ann Torac Cardiovasc Surg 2003;9:43-9.

11. Onorati F, Rubino AS, Nucera S, Foti D, Sica V, Santini F, et al. Off-pump coronary artery bypass surgery versus standard linear or pulsatile cardiopulmonary bypass: endothelial activation and inflammatory response. Eur J Cardiothorac Surg. 2010;37:897-904.

12. Ascione R, Talpahewa S, Rajakaruna C, Reeves BC, Lovell AT, Cohen A, et al. Splanchnic organ injury during coronary surgery with or without cardiopulmonary bypass: a randomized, controlled trial. Ann Thorac Surg. 2006;81:97-103.

13. Yamada $T$, Ochiai R, Takeda J, Kikuchi H, Ishibashi M, Watanabe K. Off-pump coronary artery bypass attenuates transient hepatocellular damage after myocardial revascularization. J Cardiothorac Vasc Anesth. 2005;19:603-7.

14. O'Dwyer C, Woodson LC, Conroy BP, Lin CY, Deyo DJ, Uchida T, et al. Regional perfusion abnormalities with phenylephrine during normothermic bypass. Ann Thorac Surg. 1997;63:728-35.

15. Lefor AT, Vuocolo P, Parker FB Jr, Sillin LF. Pancreatic complications following cardiopulmonary bypass Factors influencing mortality. Arch Surg. 1992;127:1225-30.

16. Wang MJ, Chao A, Huang $\mathrm{CH}$, Tsai $\mathrm{CH}$, Lin FY, Wang $\mathrm{SS}$, et al. Hyperbilirubinemia after cardiac operation. Incidence, risk factors, and clinical significance. J Thorac Cardiovasc Surg. 1994;108:429-36.
17. Riddington DW, Venkatesh $\mathrm{B}$, Boivin CM, Bonser RS, Elliott TS, Marshall T, et al. Intestinal permeability, gastric intramucosal $\mathrm{pH}$, and systemic endotoxemia in patients undergoing cardiopulmonary bypass. JAMA. 1996;275:1007-12.

18. Loef BG, Epema AH, Navis G, Ebels T, van Oeveren W, Henning RH. Offpump coronary revascularization attenuates transient renal damage compared with on-pump coronary revascularization. Chest. 2002;121:1190-4.

19. Pramodh K, Vani, Muralidhar K. Renal function following CABG: On-pump vs off-pump. Ind J Thorac Cardiovasc Surg 2003;19:169-73.

20. Mangano CM, Diamondstone LS, Ramsay JG, Aggarwal A, Herskowitz A Mangano DT. Renal dysfunction after myocardial revascularization: risk factors, adverse outcomes, and hospital resource utilization. The Multicenter Study of Perioperative Ischemia Research Group. Ann Intern Med. 1998;128:194-203.

21. Conlon PJ, Stafford-Smith M, White WD, Newman MF, King S, Winn MP, et al. Acute renal failure following cardiac surgery. Nephrol Dial Transplant. 1999;14:1158-62

22. Boodhwani M, Rubens FD, Wozny D, Nathan $\mathrm{H}$. Effects of mild hypothermia and rewarming on renal function after coronary artery bypass grafting. Ann Thorac Surg. 2009;87:489-95.

23. Shahbazi S, Parah A, Sahmeddini MA. Evaluation of factors influencing liver function test in on-pump coronary artery bypass graft surgery. Iran J Med Sc 2013;38:308-13.

24. Bierbach B, Bomberg H, Pritzer H, Prabhu S, Petzina R, Kempski O, Horstick G, Cremer J, Hoffmann G. Off-pump coronary artery bypass prevents visceral organ damage. Interact Cardiovasc Thorac Surg. 2014;18:717-26. 